\title{
Valuing water gains in the Eastern Cape's Working for Water Programme
}

\author{
SG Hosking* and M du Preez \\ Department of Economics and Economic History, University of Port Elizabeth, PO Box 1600, Port Elizabeth 6000, South Africa
}

\begin{abstract}
Water is one of the most important measured benefits of the Working for Water Programme (WWP). This programme entails the removal of high water-consuming alien vegetation and the restoration of low water-consuming indigenous vegetation. For this reason it is crucial that the pricing of this water be an accurate reflection of its relative scarcity. This paper sheds more light on this aspect. A procedure for pricing water is described and applied in six WWP projects in the Eastern Cape province: Tsitsikamma, Kouga, Port Elizabeth Driftsands, Albany, Balfour and Pott River. It is shown that the procedure yields very different prices at the different sites, and higher prices for projects that increase river flows feeding metropolitan demand.
\end{abstract}

\section{Introduction}

There is little doubt that one of the most important measured benefits of the WWP in South Africa is water. This programme entails the removal of high water-consuming alien vegetation and the restoration of low water-consuming indigenous vegetation. Not only is this benefit highlighted in the name of the project but it is pre-eminent in brochures advertising it (DWAF, 1999). It is also evident that a substantial amount of research has been conducted on the quantity of water gained through the WWP (Versveld et al., 1998; Le Maitre et al., 1996). Surprisingly though, very little research has been conducted on pricing this water benefit. A number of studies have generated prices, e.g. Marais (1998); Van Wilgen et al. (1997) and Hosking and Du Preez (1999), but there is a dearth of information on the procedures by which they were generated.

This paper examines this issue. The purpose of the paper is to recommend a procedure for pricing water generated by WWP projects. The procedure is then applied to six Eastern Cape projects - those of the Tsitsikamma, Kouga, Port Elizabeth Driftsands, Albany, Balfour and Pott River (see Fig. 1). The nature of South Africa's water markets is taken as a given.

\section{A procedure for pricing water generated}

Probably the most universal water pricing approach adopted in economic assessments of theWWP in South Africa is that of Van Wilgen et al. (1997). This study based its price on the Skuifraam Dam development, the next one scheduled to be constructed for the Cape Town metropole. [The concept price of water is used in this paper to refer to the value of water as measured by marginal cost or marginal willingness-to -pay. Some people would argue that the term tariff or value would be more appropriate (anon. referee)]. The development cost of this water supply scheme was estimated at R400 m. and the operating costs at R2 m./a. Van Wilgen et al. (1997) calculated two prices on the basis of this scheme: $\mathrm{R} 0.59 / \mathrm{m}^{3}$ on the basis that no control of alien plants took place and $\mathrm{R} 0.57 / \mathrm{m}^{3}$ on the basis that it did take place. The second value of $\mathrm{R} 0.57 / \mathrm{m}^{3}$ was

* To whom all correspondence should be addressed.

푱(041) 504-2638; fax:(041) 583-2644; e-mail: ecasgh@upe.ac.za Received 17 May 2001; accepted in revised form 29 October 2001. 
inflow supplied by the river, but the inadequacy of dam capacity. If additional river flow is gained, the requirement for the dam remains.

A second problem with the above approach to pricing is that it is limited in its applicability. The problem is not so much with the use of this price reference in other metropolitan areas (although there could be problems with this too), but with its applicability to rural areas which do not feed metropolitan water systems. In the bulk of these cases the use of costs of water storage and transfer do not yield prices which reflect relative scarcity.

If the objective of water pricing for WWP projects is to reflect relative scarcity, the following procedure may be useful.

(a) The time horizon over which one is interested in the price needs to be defined and differences in purchasing power between different years should be defined.

(b) The bulk raw water purchasers and suppliers of the water should be identified.

(c) The question of how information on water pricing is revealed though the interaction of these agents should be examined. Calculations of water prices should be made on this basis.

(d) Changes in demand and supply that are expected to impact on future prices of water should be explicitly taken into account.

Steps (a) and (b) are intended to put the factors on the table that need to be addressed in steps (c) and (d).

The most technical of these steps is (c). When supplying water to urban areas demand information is not revealed, only cost-ofsupply information is revealed. Local authorities run monopolies in the end-user market and (up until recently) have set prices merely in order to cover costs. For this reason, if water is to be used to satisfy urban demand, the only available approach is marginal cost pricing. The marginal cost of generating river water for urban demand is the unit cost of bringing additional bulk untreated river water into urban areas. It should be distinguished from average cost, which is the unit cost of all water brought into urban areas. The costs being referred to are capital, operational and maintenance costs (Sampath, 1992). The appeal of using marginal cost as a reference for pricing lies in the fact that marginal cost is an efficient price - net social benefits are maximised (Sampath, 1992; Bate et al., 1999).

In cases where additional water is generated in rivers not flowing into storage dams built to satisfy urban demand, a marginal cost approach is inappropriate. In addition, if there is excess capacity in the dam and this is being allocated to agriculture, marginal cost pricing is not appropriate because no alternative new source of water is being sought by the urban market. Typically, if demanded at all, this water is demanded for agriculture.

With respect to satisfying agricultural demand, in most cases the marginal costs of extraction are private rather than social in nature. They do not reflect external costs and are often far less than what a demand-based analysis reveals as to what farmers are willing to pay. Marginal cost to meet agricultural demand refers to dam storage cost and the private costs of pumping and transferring water by pipe or canal.

These costs are unlikely to change as a result of an alien vegetation-clearing programme and almost certainly do not reflect the real worth of the extra water generated for the farmer by this programme. This is because farmers are prepared to pay more for this water than the private marginal cost. The vegetation-clearing programme releases additional water into the river, not onto the land. To divert this additional water from the river onto the land, the private marginal cost referred to above must be incurred. The real marginal worth to agriculture of the additional water supply generated is, therefore, the excess willingness-to-pay over private marginal cost.

The private marginal cost of water in agriculture in the Eastern Cape tends to be low compared with the marginal cost to local urban authorities of obtaining water. [However, this is not the case in many other places (anon. referee). Under certain conditions (high value agricultural uses) the value of irrigation water can be just as high or even higher than the value attached to urban water (Fredericketal., 1996; Louw, 2001)]. For instance, in the Gamtoos River irrigation district (including the Kouga, Impofu and Loerie Dams) the tariff charged for water used for irrigation purposes is based solely on the catchment management cost incurred (DWAF, 2000). It is $\mathrm{R} 0.01196 / \mathrm{m}^{3}$. The estimated average water resource management charges for water used for irrigation purposes in South Africa were between R0.0016/ $\mathrm{m}^{3}$ and R0.0112/ $\mathrm{m}^{3}$ (Pretorius et al., 1998).

If, as normally appears to be the case, the water supplied is not directly charged for in water-right payments, the marginal willingness-to-pay rate will exceed marginal cost. In this case the excess benefit to the buyer of the water constitutes a benefit to land ownership and can be expected to be capitalised into land values. For this reason it has become common practice to determine the willingness-to-pay prices by reference to this capitalised portion in land value (Backeberg, 1996). In efficient markets this would equal the rental value of water. The rental value of water is its in-situ price, i.e. its value in the river (Field, 2001). Although the new National Water Act of 1998 abolished riparian water rights, the water entitlements generated prior to this time have largely been accommodated within the new allocative system. For this reason, water pricing in South Africa by reference to capitalised land values remains relevant, even if undesirable (Backeberg, 1996).

The idea of including procedural step (d) in the list above was to draw attention to the fact that prices are set in a dynamic context. There are many factors which influence the price of water over time, both from the supply and the demand sides, and they change, sometimes radically (Michelsen et al., 2000). Ideally, whichever of the above two approaches is taken to pricing water over time for conservation projects, the outcomes should be sensitised to expected changes in demand and supply. This sensitivity would entail estimating water prices for different periods. However, there is also a great hazard in following this procedure - the pricing of water becomes subject to speculative forecasting for which the information requirements are great, but the margins of error are unknown. The problem is compounded by substantial variations in water market situations between and within regions (Michelson et al., 2000).

\section{Applying relative scarcity pricing to WWP projects in the Eastern Cape}

These requirements are applied below to six WWP project sites in the Eastern Cape - the Tsitsikamma, Kouga, Port Elizabeth Driftsands, Albany, Balfour and Pott River sites. In all six cases, the time horizon over which price information was required was set at 100 years, prices were adjusted to 2000 levels (step a), and were assumed to remain constant over this period (step d).

\section{Tsitsikamma site}

\section{Selected site information}

The Tsitsikamma site falls within a mountain catchment area $\left(34^{\circ} 01\right.$ 'S; $\left.23^{\circ} 54^{\prime} \mathrm{E}\right)$ and covers an area of $128783 \mathrm{ha}$. The estimated percentage alien vegetation cover present is between 10.1 and $20 \%$. Fynbos is the indigenous ground cover found here, but it is invaded 
by black wattle and pines. The Uitenhage Group outcrop lies on either side of Plettenberg Bay and comprises gently rolling hills. The hills increase in size toward the rugged Cape Fold Mountains, which run parallel to the coastline. The elevations range from sea level to $1618 \mathrm{~m}$. The mean annual precipitation and mean annual runoff are $960 \mathrm{~mm} / \mathrm{a}$ and $342 \mathrm{~mm} / \mathrm{a}$ respectively.

\section{Primary purchasers and providers (step b)}

The runoff produced by the Tsitsikamma mountain catchment that does not flow into the sea is used for agricultural purposes (irrigation farming and livestock watering). A limited amount of water is abstracted by informal settlements for domestic use. No charge is levied on these users, except on 12 farmers who pay the Klipdrif Irrigation Board for water they receive from a storage dam.

The 12 farmers who make up the Klipdrif Irrigation Board in the Tsitsikamma area receive an annual water quota of $6000 \mathrm{~m}^{3} / \mathrm{ha}$ at a cost of R320/ha. This translates into a charge of R0.053/ $\mathrm{m}^{3}$ of water (Van der Merwe, 2000). This price was agreed upon by the farmers concerned, and covers the capital, maintenance and operational costs of the scheme. This price is one for a water storage project and not an environmental water creation project.

\section{How water pricing information is revealed (step c)}

The Klipdrif Irrigation Board is a private initiative, but Van der Merwe (2000) maintains that the annual charge (i.e. R0.053/ $\mathrm{m}^{3}$ ) represents the true cost of water in this catchment area. The Klipdrif Dam was constructed as a joint venture by local farmers. The Landbank financed (via a private loan) the capital cost of building the dam.

The money paid by members of the Klipdrif Irrigation Board in the Tsitsikamma area is not a purchase of water from a public authority, but a private cost associated with adding value. The water resources (water sources and storage facilities on individual farms) in the Tsitsikamma area were registered with the Department of Water Affairs and Forestry in accordance with the new Water Act. The farmers in the area anticipate that in the future water rights in the area will be allocated on the basis of current shares. Currently, water rights are not traded in this area.

For reasons already discussed, marginal cost pricing is inappropriate for this case, and a willingness-to-pay approach was preferable. Using this approach (income capitalisation) it was calculated that farmers in the Tsitsikamma region were willing to pay up to an average of $12.5 \mathrm{c} / \mathrm{m}^{3}$ of water excluding storage and transfer costs (Van Zyl, 2001). [The average net farm income $/ \mathrm{m}^{3}$ of water was used in this approach]. This study did not make provision for valuing smaller incremental units of water. For this reason $12.5 \mathrm{c} / \mathrm{m}^{3}$ should be considered a high estimate of the marginal value of water (assuming a declining marginal willingnessto-pay).

\section{Kouga site}

\section{Selected site iformation}

The Kouga site covers an area of 158678 ha and falls within the mountain catchment area of the Langkloof valley ( $\left.33^{\circ} 43{ }^{\prime} \mathrm{S} ; 24^{\circ} 35^{\prime} \mathrm{E}\right)$. The WWP is concentrated on the Kouga and Krom River catchments. The area has scattered alien infestations ranging in density between 5.1 and $10 \%$. The indigenous ground cover is fynbos, but the area is invaded with black wattle and pines. The topography is composed of a series of parallel mountain ranges rising step-wise up to an altitude of about $1500 \mathrm{~m}$. The mean annual precipitation and mean annual runoff are $547 \mathrm{~mm} / \mathrm{a}$ and $255 \mathrm{~mm} / \mathrm{a}$ respectively.

\section{Primary purchasers and providers (step b)}

Three main dams store water inflows from the Kouga and Krom River mountain catchments: the Churchill and Mpofu Dams on the Krom River and the Kouga Dam on the Kouga River.

These three dams have capacities of $33 \times 10^{6} \mathrm{~m}^{3}, 105 \times 10^{6} \mathrm{~m}^{3}$ and $130 \times 10^{6} \mathrm{~m}^{3}$ respectively. On average,the dams' capacities are exceeded by inflow once every 3 to 5 years. These dams form the main water supply source for the Algoa Bay region, including the Port Elizabeth-Uitenhage metropole. They are responsible for more than $80 \%$ of the water supply to the Port Elizabeth- Uitenhage metropole area and the Langkloof and Patensie irrigation schemes (Eastern Cape Ministry of Agriculture and Environmental Affairs, 1994). The principal purchasers of the water produced by these catchments are local authorities which purchase it from the Port Elizabeth Municipality (PEM). The price of water is determined in this paper with reference to information supplied by the PEM.

\section{How water pricing information is revealed (step c)}

The price for water from the Kouga area, which is levied to local authorities in the Port Elizabeth-Uitenhage metropole, is set by the PEM (now the Nelson Mandela Metropolitan authority). The price of bulk, untreated water from the Kouga catchment, paid by the local authorities in the Port Elizabeth-Uitenhage metropole amounts to $\mathrm{R} 1.51 / \mathrm{m}^{3}$ (2000 price levels). This price does not include the local storage and purification costs (Raymer, 2000) and is determined on the basis of cost recovery by the PEM.

The tariff of bulk, untreated water from the Kouga catchment, is determined by the PEM. This water is sold to local authorities in the Port Elizabeth-Uitenhage metropolitan area. It is the average cost price of getting untreated water to the point of demand. In accordance with the Department of Water Affairs and Forestry's pricing policy, this price covers capital, maintenance and operational costs (DWAF, 1999).

Several new water development schemes are under consideration or are being developed in the Kouga area, e.g. the WWP, the Tsitsikamma Scheme and the Guernakop Dam.

Clearing the Kouga and Krom River catchments (WWP) from riparian invaders has been estimated to yield approximately 9 million $\mathrm{m}^{3}$ water/a (Briers and Powell, 1993). No additional cost for water storage, transfer and treatment is necessary in this case because this infrastructure already exists and has the capacity to accommodate the extra supplies of water runoff generated in this catchment area (Raymer, 2000). Based on a unit capital cost of R3 000/ha for initial clearing and R200/ha.a for follow-up operation, the estimated cost of clearing the 7000 ha of invaded areas in the riparian zone is R21 million for initial clearing, plus R1.4 million/a for six years of follow-up clearing (Briers and Powell, 1993). Using this cost and assuming that follow-up clearing will be required once in every year to prevent re-infestation and a cost of capital rate equal to $8 \% / \mathrm{a}$, they estimated the unit reference value to be $\mathrm{R} 0.21 / \mathrm{m}^{3}$ water. For the purpose of this study this value was adjusted for inflation to arrive at a current (2000 price level) cost of R0.34/ $\mathrm{m}^{3}$. This scheme can be seen as one of new water creation.

Two alternative ways of getting bulk, untreated water to the point of demand (the P.E.-Uitenhage metropole) are also currently being explored. One proposal is that runoff from the seaward side of the Tsitsikamma Mountain catchment be captured and piped to the Kouga/Krom water supply system (known as the Tsitsikamma Scheme). This scheme has a unit reference value of $\mathrm{R} 0.57 / \mathrm{m}^{3}$ at 
1996 price levels. At 2000 price levels this unit reference value amounts to R0.74/ $\mathrm{m}^{3}$. This option would yield approximately 10 million $\mathrm{m}^{3} / \mathrm{a}$ extra flow into the PEM's current storage dams. Another proposal is to construct an additional storage dam to supply the Algoa Bay region, the Guersnakop Dam. This dam would yield approximately 26 million $\mathrm{m}^{3} / \mathrm{a}$. The unit reference value (at 1996 price levels) for this option is $\mathrm{R} 0.62 / \mathrm{m}^{3}$ (Perez, 2000). At 2000 price levels this reference value is $\mathrm{R} 0.80 / \mathrm{m}^{3}$.

The Tsitsikamma Scheme is a water-creating one, whereas the Guernakop Dam is a storage-and- transfer one. It would be an error to use the Guersnakop Dam option as an alternative to the WWP because it is a different type of water project (as already discussed).

It is deduced that the price of water saved by conservation projects in this area is the unit reference value of the Tsitsikamma Scheme, $74 \mathrm{c} / \mathrm{m}^{3}$ (i.e. cost saved of not having to transfer water from the Tsitsikamma southern flowing rivers to the Kouga System). The Tsitsikamma Scheme is an alternative water-creating project and would supply approximately the same amount of water as the WWP. It is the lowest cost alternative water supply scheme currently under consideration to satisfy the Port Elizabeth metropolitan area's demand.

\section{Port Elizabeth Driftsands site}

\section{Selected site information}

The Port Elizabeth Driftsands site is situated in and around the town of Port Elizabeth $\left(33^{\circ} 55^{\prime} \mathrm{S} ; 25^{\circ} 35^{\prime} \mathrm{E}\right)$ and covers an area of 8700 ha. It is made up of coastal dunes and includes the Baakens and Papenkuils Rivers. The estimated percentage of invading alien plant cover present is between 5.1 and $10.0 \%$. The indigenous ground cover in this area is coastal fynbos while the alien species present comprise wattle and eucalyptus. The mean annual precipitation and mean annual runoff are $490 \mathrm{~mm} / \mathrm{a}$ and $229 \mathrm{~mm} / \mathrm{a}$ respectively.

\section{Primary purchasers and providers (requirement b)}

The water in the Port Elizabeth Driftsands area is not currently being abstracted and no purchaser currently exists for this water, or is envisaged in the immediate future (Raymer, 2000). The most likely potential buyer of this water would be the PEM.

\section{How water pricing information is revealed (step c)}

The WWP in the Port Elizabeth Driftsands area focuses on the removal of alien vegetation, most notably Acacia spp., where it is believed that a sustainable groundwater resource (i.e. aquifer) exists. Studies conducted by Lomberg et al. (1996) indicate, however, that in terms of yield and water quality, the TMGS aquifer in the PEM area is not a potential source of municipal supply, unless untapped aquifers exist at greater depths than so far exploited. Raymer (2000) observes that the pockets of water that do collect in the fractured rock base of this aquifer are too small for the abstraction of this water by the PEM (in order to augment local supply) to be economically feasible.

In addition, there are contamination problems with this water. Barbour et al. (1996) conducted a study to investigate the possible contamination of groundwater resources due to the existence of the Arlington Waste Disposal Site. They installed boreholes in the area and analysed water samples. It was found that the only occurrence of groundwater within the sand succession is related to perched water of limited extent (Barbour et al., 1996). No other incidence of groundwater occurrence in the upper formations has yet been reported in the PEM area. Moreover, no water strikes yielding in excess of $0.5 \mathrm{l} / \mathrm{s}$ were encountered in the Peninsula Formation. [Raymer (2000) argues that $0.5 \mathrm{l} / \mathrm{s}$ is a negligible amount of water].

In an attempt to establish the water quality of the groundwater resource, Lomberg et al. (1996) processed approximately 800 samples over a three-year period from 48 boreholes selected to cover as much of the Cape Recife Peninsula as borehole distribution would allow. The groundwater was found to be of relatively poor quality. Furthermore, quality tended to be spatially erratic with water unable to be used for irrigation in close proximity to boreholes with marginally potable water. Electrical conductivity and chloride values tended to be high and exceeded maximum allowable limits for domestic water supply in many unrelated boreholes. Nitrates also commonly exceeded recommended limits.

All boreholes within the PEM area south of Cape Road, Port Elizabeth, derive groundwater from the same aquifer. Approximately 220 private boreholes exist, many of which pump low volumes for garden irrigation. Very few are used for domestic needs and some are sporadically used for drinking water supply (Lomberg et al., 1996).

The area to the south and east of Arlington, Port Elizabeth, comprising the Driftsand State Forest belongs to PEM and is at present undeveloped. Even if this land is developed in future, the Churchill Pipeline, which supplies water from the Churchill Dam on the Krom River, traverses the land and will be used preferentially (Lomberg et al., 1996).

The findings of the Lomberg et al. (1996) study can be summarised as follows:

- borehole yields on the Cape Recife Peninsula only average between 0.55 and $1.1 \mathrm{l} / \mathrm{s}$.

- borehole water quality is generally poor, highly erratic and seldom potable;

- the aquifer in the PEM area does not form a strategic water supply to supplement the city's needs;

- groundwater does form an indirect resource as it reduces reliance on the municipal supply for garden irrigation in times of drought; and

- widespread contamination of groundwater is thought to occur through diffuse sources related to urbanisation in Port Elizabeth.

Based on the study conducted by Lomberg et al. (1996) it is concluded that further exploitation of groundwater resources in the Port Elizabeth Driftsands area is unlikely. For this reason it is deduced that water added through water conservation projects in this area to this aquifer has zero value, i.e. that the appropriate price of water added is $\mathrm{R} 0 / \mathrm{m}^{3}$.

\section{Albany site}

\section{Selected site information}

The Albany site is situated in the upper catchment of the Kowie and Kariega Rivers (3318' 1 S; $26^{\circ} 31^{\prime} \mathrm{E}$ ) and covers an area of 11400 ha. Alien plant cover, consisting of wattle, hakea and eucalyptus trees, is estimated at 5.1 to $10.0 \%$. The indigenous ground cover is grassland and valley thicket. The topography is made up of Cape Fold mountains with exposed rocky outcrops. Rolling hills are found closer to the coast. The mean annual precipitation and mean annual runoff are $650 \mathrm{~mm} / \mathrm{a}$ and $113 \mathrm{~mm} / \mathrm{a}$ respectively. 


\section{Primary purchasers and providers (requirement b)}

The additional water produced in the Kowie mountain catchment situated in the Albany area, due to the WWP, is used mainly for agricultural purposes (livestock watering). The water of the Kowie River has a high salinity and is unsuitable for irrigation, although it is used to a limited extent for this purpose. Currently, the farmers in this area do not pay for the use of this water.

\section{How water pricing information is revealed (step c)}

There is no catchment management charge for the use of the water from these two rivers in the Albany area. Moreover, no water rights are currently being traded. The only costs incurred are private in nature - costs associated with the pumping and storage of water by farmers (Penny, 2000). These private costs differ from farm to farm depending on the distances that water needs to be piped as well as the capacity of storage facilities.

As mentioned above, there is no water rights market in this region and almost no information on specific irrigation land prices exists. For this reason no estimate of the willingness-to-pay price could be made. In cases like this one, the best option is to seek information on willingness-to-pay relating to a region with similar characteristics (Backeberg, 2001). However, due to the unique and site-specific features of the Albany area, this proved to be an almost overwhelming task. As the water from the Kowie River is mostly used for livestock watering, it has a high salinity content and is unsuitable for irrigation, our estimate is that the price of water currently being generated through the WWP in the Albany area is very close to $\mathrm{R} 0 / \mathrm{m}^{3}$.

\section{Balfour site}

\section{Selected site information}

The Balfour site is situated in the Amatola escarpment and falls in the mountain catchment of the Kat River ( $\left.32^{\circ} 31^{\prime} \mathrm{S} ; 2^{\circ} 40^{\prime} \mathrm{E}\right)$. It covers an area of 1196 ha. Invading alien plants (i.e. wattle trees) cover 1.1 to $5.0 \%$ of its area, while indigenous vegetation is made up of forests with grassland. The topography in this area is made up of Cape Fold mountains. The mean annual precipitation and mean annual runoff are $950 \mathrm{~mm} / \mathrm{a}$ and $335 \mathrm{~mm} / \mathrm{a}$ respectively.

\section{Primary purchasers and providers (requirement b)}

The water in the Kat River mountain catchment, which flows through the Balfour area, is used by community farmers located in the informal settlements near the town of Balfour (Kakana, 2000) as well as citrus farmers situated downstream from the informal settlements. These farmers do not pay for this water unless they belong to the Kat River Irrigation Board (which has 12 members).

Members of the Kat River Irrigation Board receive an annual quota of $7000 \mathrm{~m}^{3} /$ ha at a cost of R120, which translates into $\mathrm{R} 0.017 / \mathrm{m}^{3}$ of water (Roberts, 2000). This price was agreed upon by the farmers concerned, and covers the cost of capital, maintenance and operations. It is a private cost. Their water is extracted from the Kat River Dam, a dam with a capacity of $25 \times 10^{6} \mathrm{~m}^{3}$. As already stated, other farmers in the area (mainly citrus farmers abstracting directly from the river) do not pay for water that they abstract.

\section{How water pricing information is revealed (step c)}

No public charge for Kat River water is levied and water rights are not traded in the area. The preferred way of valuing this water is in terms of a willingness-to-pay approach, by calculating land value differences using the income capitalisation method. This could be done for the Balfour area, and it was found that farmers were willing to pay up to $15.75 \mathrm{c} / \mathrm{m}^{3}$ of water in excess of abstraction costs (Roberts, 2001).

\section{Pott River site}

\section{Selected site information}

The Pott River site is situated in the high-lying grass areas of the foothills of the Eastern Cape Drakensberg ( $31^{\circ} 11^{\prime}$ 'S; $\left.28^{\circ} 14^{\prime} \mathrm{E}\right)$ and covers an area of 490 ha. Invading alien plants (black and silver wattle, crack willow and populus trees) cover 0.1 to $1.0 \%$ of the area while indigenous ground cover comprises grassveld. The topography is made up of Cape Fold mountains. The mean annual precipitation and mean annual runoff are $939 \mathrm{~mm} / \mathrm{a}$ and $327 \mathrm{~mm} / \mathrm{a}$ respectively.

\section{Primary purchasers and providers (requirement b)}

Water from the Pott River catchment is used only to a limited extent for irrigation farming, domestic consumption and livestock watering (Laverock, 2000). Most of the water flows into the former Transkei region, where some of it is abstracted by informal settlements for subsistence farming. There is no storage dam in this river and no payment is collected for the water that is abstracted from the Pott River. Most of the water flows into the Umzimvubu River and from there into the sea.

\section{How water pricing information is revealed (step c)}

No price is charged for water in the Pott River area (catchment management charges are not collected and water rights are not traded) and almost no information is available on irrigation land prices. A willingness-to-pay price for the water could not be calculated. However, this problem is not serious for this case because the water currently in the Pott River is not a scarce resource from either urban or agricultural perspectives. Any extra water currently generated in the Pott River will almost certainly end up in the sea as salt water. For this reason, our estimate is that the price of water currently being generated through the WWP in the Pott River area is $\mathrm{R} 0 / \mathrm{m}^{3}$.

\section{Conclusions}

Water is with little doubt one of the most important measured benefits of the WWP. The outcomes of cost-benefit analyses, aimed at establishing the economic feasibility of WWP projects, are significantly influenced by the price given to the water benefit. For this reason it is crucial that this pricing be as accurate a reflection of relative scarcity as possible. It is concluded that marginal cost pricing is the best way of pricing water which is destined for urban markets and generated in rivers through conservation projects, but it is not the best way of pricing water generated for agricultural purposes. For the latter case, a willingnessto-pay approach is preferable.

In pricing the water benefit of WWP projects, it is important that certain procedural steps be taken. These are as follows:

- The time horizon over which one is interested in the price needs to be defined and differences in purchasing power between different years should be defined. 


\begin{tabular}{|c|c|c|}
\hline \multicolumn{3}{|c|}{$\begin{array}{c}\text { TABLE 1 } \\
\text { Prices of water for Working for Water Projects in the } \\
\text { Eastern Cape Province }{ }^{1}\end{array}$} \\
\hline Site & $\begin{array}{c}\text { Price of } \\
\text { water }\left(\mathbf{c} / \mathbf{m}^{3}\right)^{2}\end{array}$ & Valuatio \\
\hline $\begin{array}{l}\text { Tsitsikamma } \\
\text { Kouga } \\
\text { Port Elizabeth Driftsands } \\
\text { Albany } \\
\text { Balfour } \\
\text { Pott River }\end{array}$ & $\begin{array}{c}12.5 \\
74 \\
0 \\
0 \\
15.7 \\
0\end{array}$ & $\begin{array}{l}\text { willingness to pay } \\
\text { marginal cost }{ }^{4} \\
\text { potential user response } \\
\text { User response } \\
\text { Willingness to pay } \\
\text { non-scarce resource }\end{array}$ \\
\hline \multicolumn{3}{|c|}{$\begin{array}{l}{ }^{1} \text { All prices other than that for the Kouga project were derived by } \\
\text { reference to agricultural willingness-to-pay. The Kouga project's } \\
\text { water was valued by reference to urban opportunity cost calculations. } \\
{ }^{2} \text { All prices are at } 2000 \text { levels. } \\
{ }^{3} \text { Derived using information supplied by Van Zyl (2001) for the } \\
\text { Tsitsikamma area } \\
{ }^{4} \text { Raymer (2000) } \\
{ }^{5} \text { Derived using information supplied by Roberts (2001) for the Kat } \\
\text { River area }\end{array}$} \\
\hline
\end{tabular}

- The bulk raw water purchasers and suppliers of the water should be identified.

- The question of how information on water pricing is revealed though the interaction of these agents should be examined. Calculations of water prices should be made on this basis.

- Changes in demand and supply that are expected to impact on future prices of water should be explicitly taken into account.

We have shown how these steps can be applied to selected sites in the Eastern Cape WWP. Our conclusions with respect to water prices are presented in Table 1.

These prices tell a story of their own. Briers and Powell (1993) generated a cost price in a Kouga WWP project of $21 \mathrm{c} / \mathrm{m}^{3}$ at 1993 prices. Adjusted to 2000 price levels this cost would be $34 \mathrm{c} / \mathrm{m}^{3}$. The latter price exceeds the prices generated at all sites except for the one in the Kouga region, which is one generating additional water to satisfy PEM demand. It is concluded that cost- benefit analyses of WWP projects, whose primary purpose is generating water for demand other than metropolitan, are likely to yield negative results.

\section{Acknowledgements}

Support for this research by the WRC, discussions and contributions from Dr G Backeberg and the comments of anonymous referees are gratefully acknowledged.

\section{References}

BACKEBERG G (1996) Besproeiingsbeleid en Landbouwaterbestuur: Realiteite en Prioriteite. Die Suid-Afrikaanse Landbou-Unie, Pretoria.

BACKEBERG G (2001) Personal communication. Water Research Commission, Pretoria.

BARBOUR T, ROSEWARNE PN and LOMBERG CR (1996) Arlington Waste Disposal Site Hydrogeological Report and Enviromental Review. SRK (CE) Report 229014, Port Elizabeth.

BATE R, TREN R and MOONEY L (1999) AnEconometric and Institutional Economic Analysis of Water Use in the Crocodile River Catchment,
Mpumalanga Province, South Africa. Water Research Commision Report No 855/1/99.

BRIERS HJ and POWELL M (1993) The Effect of Invader Plants, Acacia Mearsnii (Black Wattle), in the Kouga and Krom River Catchments. Algoa Water Resources Systems Analysis, Port Elizabeth.

DEPARTEMENT VANLANDBOU (1995) Vaalharts Groepgemiddeldes. Glen, Vrystaat Provinsie.

DEPARTMENT OF WATER AFFAIRS AND FORESTRY (1999) Establishment of a Pricing Strategy for Water Use Charges in Terms of Section 56(1) of the National Water Act, 1998. Government Gazette 20165. No 1353, Pretoria.

DEPARTMENT OF WATER AFFAIRS AND FORESTRY (2000) Charges for Water Supplied from Government Water Works: 2000/ 2001 Financial Year. DWAF, Pretoria.

EASTERN CAPE MINISTRY OF AGRICULTURE AND ENVIRONMENTAL AFFAIRS (1994) Water Supply Scheme by Controlling Alien Invader Trees in the Krom and Kouga River Catchments. Business Plan - Internal Report.

FIELD BC (2001) Natural Resource Economics. McGraw-Hill. New York.

HOSKING SG and DU PREEZ M (1999) A cost-benefit analysis of removing alien trees in the Tsitsikamma mountain catchment. $S$. Afr. J. Sci. 95 442-448.

KAKANA TA (2000) Personal communication. Training officer. Mpofu Training Centre, Balfour.

LAVEROCK GL (2000) Personal communication. Agricultural extension officer. Department of Agriculture, Ugie.

LE MAITRE DC, VAN WILGEN BW, CHAPMAN RA and MCKELLY DH(1996) Invasive Plants in the Western Cape, South Africa: Modelling the Consequences of a Lack of Management. J. Appl. Ecol. 33 161172.

LOMBERG CR, ROSEWARNE PN, RAYMER DA and DEVEY DG (1996) Research into Groundwater Abstraction in the Port Elizabeth Municipal Area. Steffen, Robertson and Kirsten Report 191472/4 to the Water Research Commission. WRC Report No 515/1/97.

LOUW DB (2001) Modelling the Impact of a Potential Water Market in the Berg River Basin. Ph.D. Dissertation, Univ. of the Free State.

MARAIS C (1998) An Economic Evaluation of Alien Plant Control Programmes in the Mountain Catchment Areas of the Western Cape Province, South Africa. Ph.D. Thesis, Univ. of Stellenboch.

MICHELSON AM, BOOKER JF and PERSON P (2000) Expectations in water-right prices. Water Resour. Dev. 16 (2) 209-219.

PENNY W (2000) Personal communication. Agricultural extension officer. Department of Agriculture, Grahamstown.

PEREZ M (2000) Personal communication. Project Planning, Department of Water Affairs and Forestry, Pretoria.

PRETORIUS P, VAN DER MERWE P and BRANFORD J (1998) Paper on the Practical Implementation of the Department of Water Affairs and Forestry's Proposed Raw Water Pricing Policy. Department of Water Affairs and Forestry, Pretoria.

RAYMER D (2000) Personal communication. City Engineers Department, Port Elizabeth Municipality, Port Elizabeth.

ROBERTS L (2000) Personal communication. Chairman, Kat River Irrigation Board, Balfour.

ROBERTS L (2001) Personal communication. Chairman. Kat River Irrigation Board, Balfour.

SAMPATH RK (1992) Issues in irrigation pricing in developing countries. World Dev. 20 (7) 967 - 977.

VANDER MERWE IJ (2000) Personal communication. Chairman, Klipdrif Irrigation Board, Tsitsikamma.

VAN WILGEN BW, LITTLE PR, CHAPMAN RA, GÖRGENS AHM, WILLEMS T and MARAIS C (1997) The sustainable development of water resources: History, financial costs, and benefits of alien plant control programmes. S. Afr. J. Sci. 93 404-411.

VAN ZYL JL (2001) Personal communication. Agriplan, Jeffreys Bay. VERSVELD DB, LE MAITRE DC and CHAPMAN RA (1998) Alien Invading Plants and Water Resources in South Africa: A Preliminary Assessment. Stellenbosch: CSIR Division of Water, Environment and Forest Technology. 